\title{
The rates and players of denitrification, dissimilatory nitrate reduction to ammonia (DNRA) and anaerobic ammonia oxidation (anammox) in mangrove soils
}

\author{
DANICE M. LUVIZOTTO ${ }^{1}$, JULIANA E. ARAUJO ${ }^{1}$, MICHELE DE CÁSSIA P. SILVA ${ }^{1,2}$, ARMANDO C. F. \\ DIAS $^{1}$, BEATE KRAFT ${ }^{3,4}$, HALINA TEGETMEYE ${ }^{3,5}$, MARC STROUS ${ }^{3,5,6}$ and FERNANDO D. ANDREOTE ${ }^{1}$ \\ ${ }^{1}$ Department of Soil Science, "Luiz de Queiroz" College of Agriculture, University of \\ São Paulo, Avenue Pádua Dias 11, 13418-900 Piracicaba, SP, Brazil \\ ${ }^{2}$ Department of Environmental Sciences, Federal University of São Carlos. Rod. \\ João Leme dos Santos, s/n, 18052-780 Sorocaba, SP, Brazil \\ ${ }^{3}$ Microbial Fitness Group, Max Planck Institute for Marine Microbiology, Celsiusstrasse 1, D-28359 Bremen, Germany \\ ${ }^{4}$ Nordic Center for Earth Evolution, University of Southern Denmark, DK-5230, Odense, Denmark \\ ${ }^{5}$ Center for Biotechnology, University of Bielefeld, D-33594, Bielefeld, Germany \\ ${ }^{6}$ Department of Geoscience, University of Calgary, T2N1N4, Calgary, Alberta, Canada
}

Manuscript received on April 18, 2018; accepted for publication on June 29, 2018

\begin{abstract}
How to cite: LUVIZOTTO DM, ARAUJO JE, SILVA MCP, DIAS ACF, KRAFT B, TEGETMEYE H, STROUS M AND ANDREOTE FD. 2019. The rates and players of denitrification, dissimilatory nitrate reduction to ammonia (DNRA) and anaerobic ammonia oxidation (anammox) in mangrove soils. An Acad Bras Cienc 91: e20180373. DOI 10.1590/0001-3765201820180373.
\end{abstract}

\begin{abstract}
Mangroves are ecosystems located in the transition zone between land and sea, characterized by periodic flooding that confer to its unique characteristics. Little is known about the transformation of nutrients that occur during the organic matter degradation in this system. In this study, we monitor the nitrogen transformations in soils from three mangroves with distinct levels of contamination using labeled 15NO3-. We also screened the mangroves metagenomes for the presence of genes that encode enzymes involved in denitrification (nirS, nirK, nosZ, norB and narG), anaerobic oxidation of ammonia (anammox) (hh, hao and hzo) and dissimilatory nitrate reduction to ammonium (DNRA) (nrfA). The transformations of 15NO3- indicated the balance of denitrification over anammox and DNRA in all three mangroves, with lower rates of processes in the mangrove affected by oil contamination. The metagenomic analysis detected 56 sequences related to denitrification, 19 with anammox and 6 with DNRA. Genes related with denitrification were phylogenetically distributed among several groups of bacteria (mainly Gammaproteobacteria). Anammox and DNRA related sequences were affiliated with Planctomycetes and Gammaproteobacteria, respectively. Thus, metagenomic and functional approaches supported the description of denitrification, anammox and DNRA rates in mangrove soils, and identified the major bacterial groups involved in these processes.
\end{abstract}

Key words: $\mathrm{N}$ cycling, anaerobiosis, metagenome, environmental contamination.

Correspondence to: Fernando Dini Andreote

E-mail: fdandreo@gmail.com

ORCid: http://orcid.org/0000-0002-9883-9968

* Contribution to the centenary of the Brazilian Academy of

Sciences. 


\section{INTRODUCTION}

Mangroves are important coastal ecosystems found in transition zones between marine and freshwater ecosystems such as estuaries, bays, and lagoons (Holguin et al. 1999, 2001). These ecosystems constitute a large portion (60-70\%) of the coastline in the tropical and subtropical regions (Sahoo and Dhal 2009), and play a major socio-economic role to human communities in developing countries. They not only provide protection from tidal erosion, storm surges and trap sediment for land accretion but also play an important role in biogeochemical transformations in coastal ecosystems (Lacerda et al. 1993).

The microbial community present in mangrove soils is strongly influenced by biogeographical, anthropogenic, and ecological properties, including the food web in the ecosystem, nutrient cycling, and the presence of organic and inorganic compounds in the sediment (Ghosh et al. 2010). These sediments differ from common soils mainly due to their low availability of oxygen, salinity, and highly reductive redox potential, which makes organic matter hard to degrade, thus limiting the availability of nutrients (Holguin et al. 2001, Ferreira et al. 2010). Because of the accumulation of organic matter and biochemically reductive characteristics, this is an interesting ecosystem to study the transformations of nitrate/nitrite in the nitrogen cycle. Furthermore, the high litterfall, its degradation and re-mineralization, is one of the factors contributing to high nitrogen concentrations in mangrove soils (Fernandes et al. 2012).

The nitrate present in sediments, derived from the degradation of organic compounds (Mulder et al. 1995, Rivera-Monroy et al. 1996) and subsequent oxidation of ammonium to nitrate, may be used by several competing microbial processes such as denitrification, the complete reduction of nitrate into $\mathrm{N}_{2}$, dissimilatory nitrate reduction to ammonium (DNRA), and anaerobic ammonia oxidation (anammox), where nitrite is combined with ammonium, generating water and $\mathrm{N}_{2}$ as the final products (Strous and Jetten 2004). In mangroves, as in most of the natural ecosystems, the nitrogen cycle is predominantly mediated by microbes rather than chemical processes. Denitrification may be performed by facultative aerobic microorganisms, which are found in all domains of life (Bacteria, Archaea and Eukarya) (Francis et al. 2007). DNRA is known to be catalyzed primarily by facultative and obligatory fermentative bacteria and has been documented in anaerobic sludge, anoxic sediments, and the rumen (Tiedje et al. 1988, Bonin 1996, Nijburg et al. 1997, Giblin et al. 2013, Balk et al. 2015). Anammox is performed by bacteria that form a monophyletic clade in the phylum Planctomycetes (Jetten et al. 2009, Quan et al. 2008, Strous and Jetten 2004).

The main enzymes involved in denitrification are the nitrate and nitrite reductases (encoded by the structural genes nar $\mathrm{G}, \operatorname{nap} A B$, nirK and nir S) (Reyna et al. 2010, Glockner et al. 1993), nitric oxide reductases (encoded by genes nor $\mathrm{BC}$ and nor $\mathrm{Z}$ ), and nitrous oxide $\left(\mathrm{N}_{2} \mathrm{O}\right)$ reductase (encoded by nosZ) (Throback et al. 2004, Chon et al. 2009). DNRA is performed with a dissimilatory nitrite reductase (encoded by $n r f \mathrm{AB}$, Mohan and Cole 2007), and the enzymes involved in anammox are the hydrazine hydrolase (gene $h h$ ) (Strous et al. 1999, Strous and Jetten 2004), hydroxylamine oxidoreductase (product of the hao gene) and hydrazine-oxidoreductase (encoded by the $h z o$ gene) (Shimamura et al. 2007).

In this study, we have used ${ }^{15} \mathrm{NO}_{3}^{-}$-labeling techniques to compare the rates of the three processes in Brazilian mangrove soils, where a strong competition between microorganisms and plants for the available forms of nitrogen in the ecosystem can be expected. In addition, we screened three mangroves metagenomes for genes that encode enzymes involved in these steps of the nitrogen transformations. The combination of these 
approaches allowed the functional determination of its occurrences and the identification of major bacterial players in each process.

\section{MATERIALS AND METHODS}

\section{MANGROVE DESCRIPTION AND SAMPLING}

The mangroves sampled in this study are located in the city of Bertioga, State of São Paulo, Brazil. Although they are located in the same city, these mangroves are in different states of conservation. One of them has been affected by oil contamination in 1983, when a volume of 35 million liters of oil was released into this mangrove area. This oilcontaminated mangrove is clearly divided into two sub-regions, separated by a small stream that crosses the mangrove. In the inland area of the river, here named BrMgv02 (235' $49^{\prime}$ 'S, $\left.46^{\circ} 12^{\prime} 28^{\prime} \mathrm{W}\right)$, the oil effects are still present, even several years after the spilt, with native vegetation still undergoing recovery; in the State of São Paulo, the mangrove forest is composed mainly by three species: Avicennia shaueriana, Laguncularia racemosa, and Rhizophora mangle, but for the area highly affected by the oil spilt the vegetation is clearly affected, composed by a lower density of plants, with the absence of $R$. mangle. In the area closest to the sea, named BrMgv01 (235' $43^{\prime}$ 'S, $46^{\circ} 12^{\prime} 28^{\prime} \mathrm{W}$ ), it is not possible to observe effects of the oil spilt, possibly due to its isolation from the oil drainage promoted by the stream. In addition to these two, a third place was also sampled, named

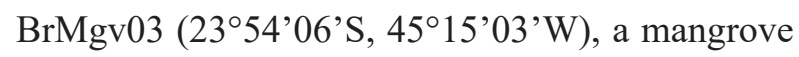
located near the city centre, suffering the effects of waste water and other contaminants dumped into the sea near the area.

The samples were collected in January of 2011. In each of the three sub-regions described above, three replicate samples were taken, which consisted of sediment cores collected via a cylindrical steel sampler $(7 \mathrm{~cm}$ diameter $\times 20 \mathrm{~cm}$ depth). For the nitrogen transformation experiments, the sediment samples were homogenized in the laboratory, generating three samples per area (in total nine) which were used for incubations with labeled nitrogen compounds.

\section{CHARACTERIZATION OF SEDIMENT SAMPLES}

At the moment of sampling, electrical conductivity and salinity parameters were recorded. In addition, sand:silt:clay content, $\mathrm{pH}$, humidity, organic matter, total nitrogen, total carbon, organic carbon and total sulphur were determined in all samples in collaboration with the Laboratory of Soil Analysis at "Luiz de Queiroz" College of Agriculture (ESALQ/USP, Piracicaba, Brazil), according to the methodology described by Van Raij et al. (2001; Table I). The concentration of ammonium, nitrate and nitrite was obtained using Standard Spectrophotometric Method (Solórzano 1969, Crompton 2005). Due to the concentration values of nitrate and nitrite, these compounds were not detected by colorimetric methods (Supplementary Table S1).

TABLE I

Physical and chemical characteristics of soil samples collected in the three mangrove areas (modified from Dias et al. 2011).

\begin{tabular}{lccc}
\hline Parameters & BrMgv01 & BrMgv02 & BrMgv03 \\
\hline Physical & & & \\
Sand:silt:clay & $34: 60: 06$ & $52: 38: 10$ & $63: 33: 05$ \\
\hline Chemical & & & \\
pH & 6.9 & 6.6 & 6.9 \\
Humidity (\%) & 65.2 & 59.0 & 76.1 \\
Organic matter (\%) & 10.9 & 11.9 & 10.5 \\
Total N (\%) & 0.13 & 0.38 & 0.30 \\
Total C (\%) & 6.03 & 6.61 & 5.69 \\
Organic C (\%) & 5.33 & 5.34 & 4.86 \\
Total S (\%) & 0.31 & 0.34 & 0.23 \\
Conductivity (mS) & 8.98 & 11.5 & 10.7 \\
Salinity (\%) & 0.47 & 0.47 & 0.41 \\
\hline
\end{tabular}


DETERMINATION OF ANAMMOX, DENITRIFICATION AND DNRA RATES BY

${ }^{15} \mathrm{~N}$-LABELED INCUBATIONS

Potential rates of anammox and denitrification were estimated by the method of Thamdrup and Dalsgaard (2002), modified according to RisgaardPetersen et al. (2003). Briefly, we prepared gas tight bags for the sediment incubations, $20 \mathrm{~cm}$ x $20 \mathrm{~cm}$ size, produced from a single sheet of plastic (Rolf Bayer Vacuum Packaging GmbH, Germany). The plastic bags were equipped with a glass outlet via a screw cap and two gaskets. The opening in the outlet was sealed with a rubber stopper (Hansen et al. 2000). Inside the bags, $300 \mathrm{ml}$ of artificial seawater medium of ambient salinity $(0.144 \mathrm{~g} / \mathrm{L}$ of Red Sea Salt, Arcadia Germany) were mixed with $100 \mathrm{ml}$ of fresh sediment (to obtain a final salinity of $0.6 \%$ ) and remaining gas was removed. In total nine bags were prepared (3 replicates x 3 mangroves) per incubation. In order to allow the development of anoxic conditions, the experiments started 12 hours after the abovementioned preparation. The incubations started with the addition of labeled nitrate plus unlabeled ammonium to the $400 \mathrm{ml}$ bags (final concentrations of $0.1 \mathrm{mM} \mathrm{Na}{ }^{15} \mathrm{NO}_{3}{ }^{-}$and 0.5 $\mathrm{mM}^{14} \mathrm{NH}_{4}^{+}$). At intervals of $1.5 \mathrm{~h}$, liquid samples were collected gently with a syringe and transferred to exetainers (5.9 mL, Exetainers, UK), prepared with $0.2 \mathrm{ml} \mathrm{HgCl}_{2}$ to stop biological activity inside the vial. Samples were collected at periods of $0,1.5$, 3.0, 4.5 and 6.0 hours, in triplicate for each time point. A headspace was set in the exetainers by the addition of $1.5 \mathrm{~mL}$ argon gas with a syringe. Rates of anammox $\left({ }^{29} \mathrm{~N}_{2}\right)$ and denitrification $\left({ }^{30} \mathrm{~N}_{2}\right)$ were measured by quantifying the production of the two forms of $\mathrm{N}_{2}$ (i.e., ${ }^{14} \mathrm{~N}^{15} \mathrm{~N}$ and ${ }^{15} \mathrm{~N}^{15} \mathrm{~N}$ ) and determined by isotope ratio mass spectrometry (IRMS system, Finigan MAT, Bremen, Germany). The values of ${ }^{29} \mathrm{~N}_{2}$ (anammox) and ${ }^{30} \mathrm{~N}_{2}$ (denitrification) production were used in the equation described by Thamdrup and Dalsgaard (2002) to calculate anammox and denitrification total rates (expressed in $\mathrm{nmol}^{29} \mathrm{~N}_{2} / \mathrm{L} / \mathrm{h}$ and $\mathrm{nmol}^{30} \mathrm{~N}_{2} / \mathrm{L} / \mathrm{h}$ ).

$\mathrm{NO}_{\mathrm{x}}^{-}$concentrations at each time point were measured with a $\mathrm{NO}_{\mathrm{x}}^{-}$analyzer (NOx analyser model 42c, Thermo Environmental Instruments Inc., Bremen, Germany) using the vanadium chloride reduction method, according to Braman and Hendrix (1989). A $\mathrm{KNO}_{3}$ curve with known values was used to calibrate the values obtained. To quantify the dissimilatory nitrate reduction to ammonium (DNRA) the consumption rate of nitrate and nitrite was measured. Rates of DNRA were estimated by subtracting the nitrate and nitrite consumption obtained in the anammox and denitrification experiment above $\left(\mathrm{NO}_{\mathrm{x}}^{-}\right)$from the overall nitrate and nitrite consumption.

To support the rates obtained in these two methodologies, the concentration of ammonium, nitrate and nitrite was monitored in the sediments samples along the incubations, as explained above.

\section{SEQUENCING OF ENVIRONMENTAL DNA FROM} MANGROVE SEDIMENTS

Environmental DNA was sequenced as described previously by Andreote et al. (2012). Briefly, from each of the three mangrove areas, aliquots of $0.3 \mathrm{~g}$ of homogenized sediment were subjected to DNA extraction using the Power Soil DNA Isolation kit (MoBio ${ }^{\circledR}$ Laboratories Inc., Carlsbad, CA, USA). After the extractions, DNA from all samples were pooled together by mangrove (approximately 20 ng $\mu 1^{-1}$ of DNA from each extraction - from a total of $100 \mu \mathrm{l})$, and concentrated in a speed vacuum centrifuge $(3,000 \mathrm{rpm}$ for $30 \mathrm{~min})$ to a final volume of $10 \mu 1$. A NanoDrop (Thermo Scientific, Wilmington, DE, USA) spectrophotometer was used to obtain an accurate quantification of the extracted DNA and to verify DNA quality.

The extracted DNAs from the Brazilian mangrove soils were subjected to pyrosequencing using 454 GS FLX Titanium technology at Roche Applied Sciences (Indianapolis, IN, USA). 
A quarter of one 454 plate was used for each mangrove area (BrMgv01 to BrMgv03). Obtained sequences were quality trimmed using a minimum length of $30 \mathrm{bp}$, quality cut-off $\geq 20$, and a window size of $20 \mathrm{bp}$. The total numbers of trimmed valid reads obtained for each metagenome used in this study were 249,993 for BrMgv01 (average size 235.2 bases, $55.75 \%$ GC content), 231,233 for BrMgv02 (average size 238.2 bases, 54.64\% GC content), 214,921 for BrMgv03 (average size 247.9 bases, $56.36 \%$ GC content). The clean sequences were uploaded to the metagenomic RAST server (MG-RAST) (Meyer et al. 2008) made publicly accessible under the codes 4451033.3, 4451034.3 and 4451035.3 for mangroves BrMgv01, BrMgv02 and BrMgv03, respectively. For more details on sequence analyses please see Andreote et al. (2012)

\section{SELECTION OF GENES RELATED TO THE NITROGEN CYCLING}

For the detection of targeted genes, a collection of selected protein sequences for each functional gene of interest was used for a tBLASTn search against the metagenomic reads (with E-value cutoff 0.001). The reads selected for this study are involved in nitrogen pathways, denitrification (nirK, nirS, nos $\mathrm{Z}$, nor B and narG genes); anammox (hh, hao and hzo genes) and DNRA (nrfA). These genes were selected due to their importance in the nitrogen cycle and also common use as functional biomarkers to track the targeted transformations.

The selection of sequences to be used in this approach was performed in three steps. First, protein sequences from all prokaryotic sequenced genomes available at NCBI (<FTP://ftp.ncbi.nlm.nih.gov/ Bacteria $>$ ) were extracted. Second, the sequences that were similar to those obtained in step one were extracted from our metagenomes by tBLASTn and added to the database. Finally, available (putative) protein sequences of target functional genes from uncultured prokaryotes were retrieved from Uniprot
$(<$ http://www.uniprot.org $>)$ and from FunGene $(<$ http://fungene.cme.msu.edu/index.spr $>$ ).

To decrease redundancy, the retrieved sequences were clustered at $90 \%$ identity using the Uclust software and only the seed sequences of the resulting clusters were tagged and added to the final gene validation database. Metagenomic reads selected from the initial tBLASTn searches were validated by BLASTp (no E-value cutoff) against the validation database including the selected sequences. A read was considered 'validated' if a hit with a tagged sequence (of the expected functional gene) was among the first 50 hits for this read. Thus, sequences identified as related with these genes/enzymes were extracted from metagenomic data and subjected to a BLASTp search, where it was possible to determine the taxonomic affiliation of these sequences up to the class level.

All inferences on the abundance of sequences affiliated with each process or each taxonomical group was made on the basis of the normalized rate of occurrence, determined by dividing the number of sequences observed by the total number of reads from each metagenomic dataset.

\section{RESULTS}

\section{CHARACTERISTICS OF MANGROVE SOILS}

A higher content of sand was observed in BrMgv03, followed by BrMgv02 and BrMgv01. Samples from BrMgv03 also had higher values of humidity (76.06\%). Values of organic matter, total nitrogen, total carbon, organic carbon, total sulphur and conductivity tended to be higher in BrMgv02 (Table I). There was little variation in $\mathrm{pH}$ among mangrove samples. Samples collected from mangroves BrMgv01 and BrMgv02 had a higher salinity.

Prior to the incubations, the concentration of ammonium $\left(\mathrm{NH}_{4}^{+}\right)$was higher in samples from BrMgv01 (147.7 $\mu \mathrm{M})$ and BrMgv03 $(183.7 \mu \mathrm{M})$ when compared to BrMgv02 $(90.0 \mu \mathrm{M})$. The 
concentration of nitrate was higher in mangrove BrMgv03 $(600 \mu \mathrm{M})$, while others presented lower values $(160 \mu \mathrm{M})$. Along incubations, the amounts of nitrite were constant in the area BrMgv03, presented a decrease in the last time point for BrMgv02, and in the BrMgv01, the concentration was initially increased, followed by a temporal decrease (Supplementary Material - Table SI).

DETERMINATION OF ANAMMOX,

DENITRIFICATION AND DNRA RATES IN

MANGROVE SEDIMENTS

The incubations of sediments with ${ }^{15} \mathrm{NO}_{3}$ - showed the differential potential rates of the targeted processes in each mangrove studied. Denitrification was predominant over anammox in all three mangroves. The values for production of ${ }^{29} \mathrm{~N}_{2}$ (indicative of anammox) were $0.10,0.03$ and $0.90 \mu \mathrm{mol} / \mathrm{L} / \mathrm{h}$ for BrMgv01, BrMgv02 and BrMgv03, respectively (Figure 1a). In counterpart, the total releases of ${ }^{30} \mathrm{~N}_{2}$ (indicative of denitrification) were 2.08, 0.34 and $2.94 \mu \mathrm{mol} / \mathrm{L} / \mathrm{h}$ for BrMgv01, BrMgv02 and BrMgv03, respectively (Figure 1b). Both processes were suppressed in samples collected in the oilaffected area (BrMgv02).

The denitrification rates obtained were: 49.83 $\pm 4.72 \mu \mathrm{mol} / \mathrm{L} / \mathrm{d}$ in BrMgv01; $10.94 \pm 2.90 \mu \mathrm{mol} /$ $\mathrm{L} / \mathrm{d}$ in BrMgv02 and $70.52 \pm 2.75 \mu \mathrm{mol} / \mathrm{L} / \mathrm{d}$ in BrMgv03. Anammox rates observed were $2.40 \pm$ $0.43 \mu \mathrm{mol} / \mathrm{L} / \mathrm{d}$ in BrMgv01, $0.66 \pm 0.18 \mu \mathrm{mol} / \mathrm{L} / \mathrm{d}$ in BrMgv02 and $2.03 \pm 0.093 \mu \mathrm{mol} / \mathrm{L} / \mathrm{d}$ in BrMgv03. These results showed that denitrification rates are much higher than those of anammox, around 20-fold higher in BrMgv01, 16.5-fold higher in BrMgv02 and 34.5-fold higher in BrMgv3.

The consumption of $\mathrm{NO}_{\mathrm{x}}^{-}$compounds during six hours of incubation also allowed the quantification of DNRA in mangrove soils, with rates that varied among mangroves. Results indicated that mangrove BrMgv02 showed the highest $\mathrm{NO}_{\mathrm{x}}^{-}$consumption (-7.66 $\left.\mu \mathrm{mol} \mathrm{NO}_{\mathrm{x}}^{-} / \mathrm{L} / \mathrm{h}\right)$, followed by BrMgv03 (-7.27

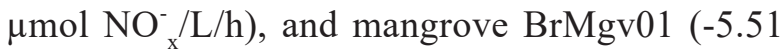
$\mu \mathrm{mol} \mathrm{NO}-/ \mathrm{L} /$ hour) (Figure 2).

METAGENOMIC ASSESSMENT AND TAXONOMIC AFFILIATION OF GENES RELATED TO NITROGEN TRANSFORMATIONS IN MANGROVES SOILS

The total number of reads obtained for each metagenome was 249.993 for BrMgv01, 231.233 for BrMgv02 and 214.921 for BrMgv03. From this total, our approach allowed us to identify a total of 81 sequences related to nitrogen cycle transformations [56, 19 and 6 sequences related to denitrification (genes narG, nirK, nirS, norB and nosZ), anammox (genes $h h, h z o$ and $h a o$ ) and DNRA ( $n r f A)$, respectively] (Figure 3 and Table SII). With the exception of $\operatorname{nar} G$, the low number of sequences retrieved for most genes did not enable us to make inferences about possible differences in the abundance of genes in mangrove sediments. The mangrove metagenomes displayed the highest number of reads for narG compared to the other denitrification genes (Figure 3 and Table SII).

Regarding the relative proportion of reads involved in each process (normalization per 100,000 sequences), we observed that mangrove BrMgv01 showed the higher number of reads related to denitrification (10.80), followed by anammox $(1,60)$ and DNRA (0.80) (Table II). Mangrove BrMgv02 showed a lower number of reads involved in all three processes, compared to the other two areas (Table II), with a higher number of reads involved in denitrification (4.76), followed by anammox (1.73) and DNRA (0.86). Mangrove BrMgv03 showed a similar trend as observed for mangrove BrMgv02 (Table II).

The taxonomic affiliation of the sequences indicated the main bacterial classes harboring the genes involved in the processes studied here, and suggested that the diversity of groups harboring the genes related to anammox and DNRA is much lower, compared to denitrification (Figure 4). Sequences related to anammox (genes $h h$ and $h z o$ ) 

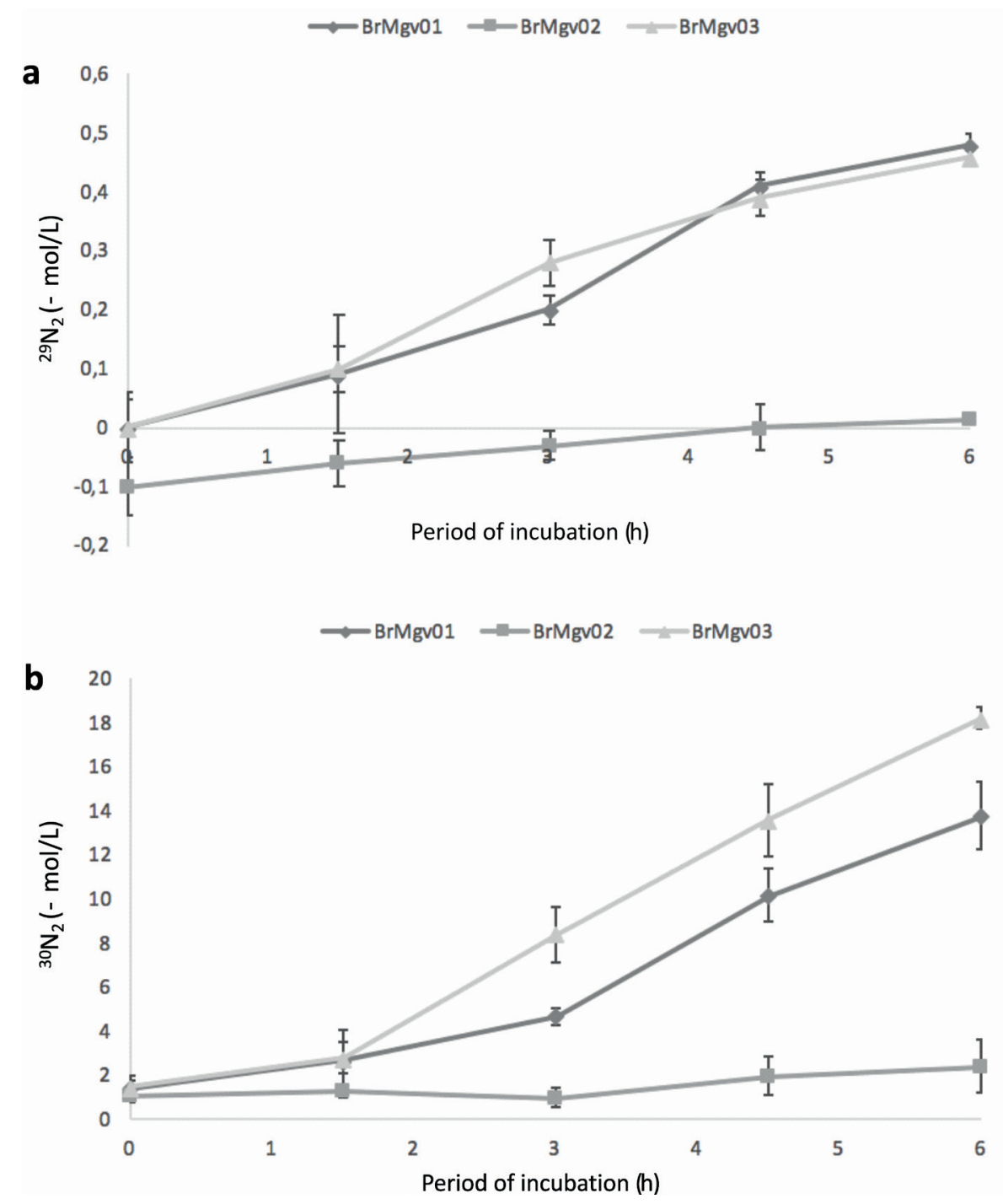

Figure 1 - The dynamics of ${ }^{29} \mathrm{~N}_{2}$ (a) and ${ }^{30} \mathrm{~N}_{2}$ (b) in the isotopic enrichment experiments of mangrove soils.(Each data point represents the average of three incubations; bars indicate standard error of the mean.

were predominantly affiliated to Planctomycetes, except for those from BrMgv02, mainly affiliated to Deltapropteobacteria (Figure 4). Sequences identified as related to $n r f A$ genes, which are associated with DNRApathway, were taxonomically affiliated only with Gammaproteobacteria (Figure 4). Sequences of genes related to denitrification were phylogenetically distributed along distinct groups depending on the mangrove area analyzed. Overall, sequences were mostly affiliated with Gammaproteobacteria (nos $Z$ and nar $G$ genes) and Alphaproteobacteria (nirK and nirS genes) (Figure 4). Mangrove BrMgv02 was the most diverse sample (nine bacterial classes identified), followed by BrMgv03 (six classes) and BrMgv01 (four classes). In the BrMgv01 there was a predominance of sequences affiliated with Alphaproteobacteria, Gammaproteobacteria and Bacteroidetes, followed by the abundance of genes related to Betaproteobacteria, whereas in BrMgv02 no sequence was affiliated with Bacteroidetes, but Alpha- and Gammaproteobacteria remain 
TABLE II

Normalized number of sequences affiliated to distinct transformations of nitrogen, found in the mangrove soil metagenomes. Values represent number of sequences in each 10,000 sequences of metagenomes.

\begin{tabular}{cccc}
\hline & Denitrification & Anammox & DNRA \\
\hline BrMgv01 & 10.80 & 1.60 & 0.80 \\
BrMgv02 & 4.76 & 1.73 & 0.86 \\
BrMgv03 & 10.70 & 5.12 & 0.93 \\
\hline
\end{tabular}

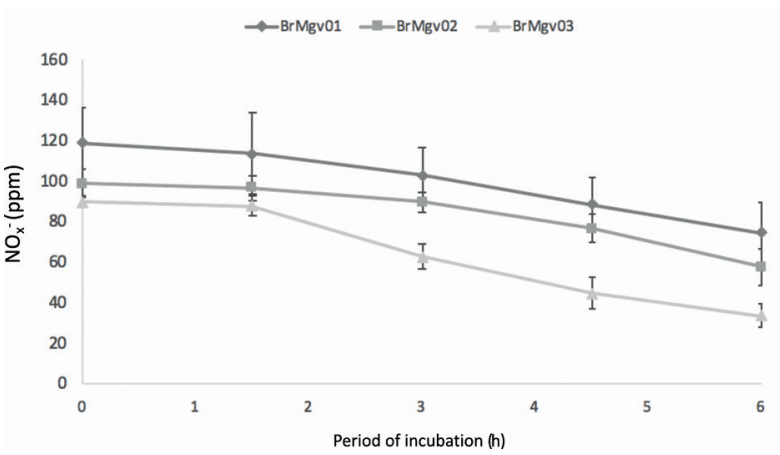

Figure 2 - Concentrations of $\mathrm{NO}_{3}{ }^{-} / \mathrm{NO}_{2}{ }^{-}$in mangrove soils along the isotopic experiment. Values represent average values of three replications and bars reveal the standard error of the mean.

dominant for denitrification-related genes in this area. In mangrove BrMgv02 the number of classes observed was higher, with a higher proportion of those from Alphaproteobacteria and Gammaproteobacteria, followed by other classes such as Betaproteobacteria and Bacilli (Figure 4).

\section{DISCUSSION}

The taxonomical composition of microbial communities inhabiting mangrove soils is widely described (Andreote et al. 2012, Thompson et al. 2013, Jiang et al. 2013, Nogueira et al. 2015). In the last years, we have gained insights about the occurrence of differential microbiomes in mangroves under distinct stages of preservation (Andreote et al. 2012, Dias et al. 2012, Nogueira et al. 2015). In counterpart, the activities of these microbes in the biogeochemical cycles have been mostly based on indirect approaches (Andreote et al. 2012), such as gene abundances. Therefore, in this study, we performed experiments with labeled nitrogen $\left({ }^{15} \mathrm{~N}\right)$ compounds and metagenomics to better understand the actual rates of the nitrogen cycling processes, denitrification, anammox and DNRA.

Although some studies in mangroves and other anaerobic soils have indicated high anammox activity (Meyer et al. 2005), we observed that denitrification predominates and co-operates with DRNA in all three mangroves assessed in the present study. Similar results were previously observed in shrimp pond sediments and mangroves (Balk et al. 2015), also specifically in Vietnam (Amano et al. 2011), in the Amundsen Sea Polynya in Antarctica (Choi et al. 2016) and in Southeast China (Cao et al. 2017). The high rates of denitrification might be explained by the availability of organic energy sources and $\mathrm{NO}_{2}{ }^{-}$(Trimmer et al. 2003, Meyer et al. 2005), since $\mathrm{NH}_{4}^{+}$is rarely limiting in sediments (Risgaard-Petersen et al. 2003, Meyer et al. 2005). Moreover, in conditions that stimulate sulfate reduction, sulfide-based denitrification might be favored competing with anaerobic ammonium oxidation, which is repressed in the presence of $\mathrm{H}_{2} \mathrm{~S}$ (Dalsgaard et al. 2003). Possibly, the main cause for the differences observed here is the environmental contamination, as denitrification is a process known to be performed by a wide diversity of bacteria (Allison and Martiny, 2008).

According to Balk et al. (2016), in forest soil ecosystems, a variety of taxonomically unrelated bacterial groups are capable of denitrification, with $96 \%$ of cultured denitrifiers belonging to the Gammaproteobacteria. Previous studies have indicated that abundance and diversity of genes involved in denitrification in sediments might be affected by many factors, including concentration gradient of the dissolved inorganic nitrogen, organic matter content, dissolved oxygen, and redox potential (Dong et al. 2009, Reyna et al. 2010). In our approach, the affiliation of sequences 


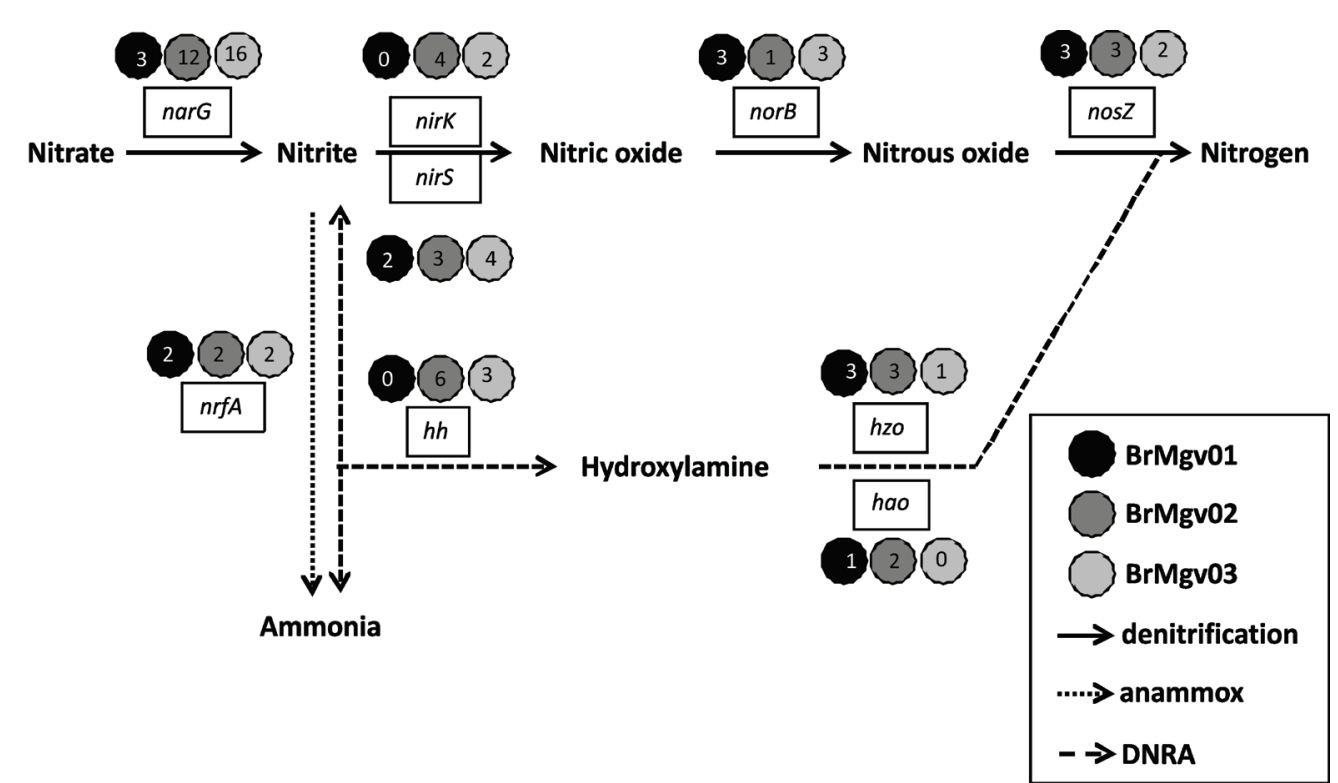

Figure 3 - Functional genes involved in the nitrogen cycle detected in metagenomic reads. The reads selected for this study are involved in denitrification (identified nir $\mathrm{K}, \operatorname{nos} \mathrm{Z}$, nor $\mathrm{B}$ nar G genes, and also considered nirS gene); anammox ( $h$, hao and hzo genes) and DNRA (nrfA), in each mangrove analyzed.

associated with denitrification revealed to be more diverse in the mangrove contaminated by the oil spilt (BrMgv02). Possibly, this response of the system is associated with the removal of prevalent conditions in other systems, limiting the development of highly specialized groups, and further opening niches for others players in this transformation, what is connected to the intermediate disturbance theory (Padisák et al. 1993), where diversity is high when disturbances occur at an intermediate frequency and/or intensity.

In mangrove systems, $55 \%$ of the nitrogen loss (as $\mathrm{NO}, \mathrm{N}_{2} \mathrm{O}$ or $\mathrm{N}_{2}$ ) is known to occur through denitrification (Fernandes et al. 2012). However, anammox bacteria could be also responsible for a significant portion of the loss of fixed nitrogen, as observed in the oceans (Strous and Jetten 2004), and might account for up to $67 \%$ of the nitrogen removal in marine sediments by shunting nitrogen directly from $\mathrm{NH}_{4}^{+}$and $\mathrm{NO}_{2}^{-}$under anaerobic conditions (Thamdrup and Dalsgaard 2002). It was well known that $\mathrm{NO}_{2}^{-}$is the oxidized substrate for the anammox process (Dalsgaard et al. 2003,
Risgaard-Petersen et al. 2003, Thamdrup and Dalsgaard 2002, Trimmer et al. 2003), although recent research suggests that some cultivated anammox bacteria can reduce $\mathrm{NO}_{3}^{-}$to $\mathrm{NO}_{2}^{-}$with propionate as the electron donor (Holtappels et al. 2011). Furthermore, marine anammox bacteria, in contrast to their competitors (the denitrifiers) appear to require a continuous supply of $\mathrm{NO}_{\mathrm{x}}^{-}$ $\left(\mathrm{NO}_{3}^{-}\right.$plus $\left.\mathrm{NO}_{2}^{-}\right)$to maintain an active enzyme apparatus (Risgaard-Petersen et al. 2003, Meyer et al. 2005). Given that $\mathrm{NH}_{4}^{+}$is rarely limiting in sediments, the availability of $\mathrm{NO}_{2}^{-}$most likely controls the abundance of active anammox bacteria (Meyer et al. 2005). Indeed, high rates of anammox occur in estuarine sediments with permanently high concentrations of $\mathrm{NO}_{2}^{-}$(Risgaard-Petersen et al. 2003). Also, high $\mathrm{NO}_{3}^{-}$concentrations are known to support anammox rates. Dalsgaard et al. (2003) explain that in inorganic-rich sediments, denitrification is more responsive to organic carbon loading than anammox. In high organic matter content conditions, higher demand for electron acceptor is created (i.e. $\mathrm{NO}_{2}{ }^{-}$and $\mathrm{NO}_{3}{ }^{-}$) and a smaller 
a

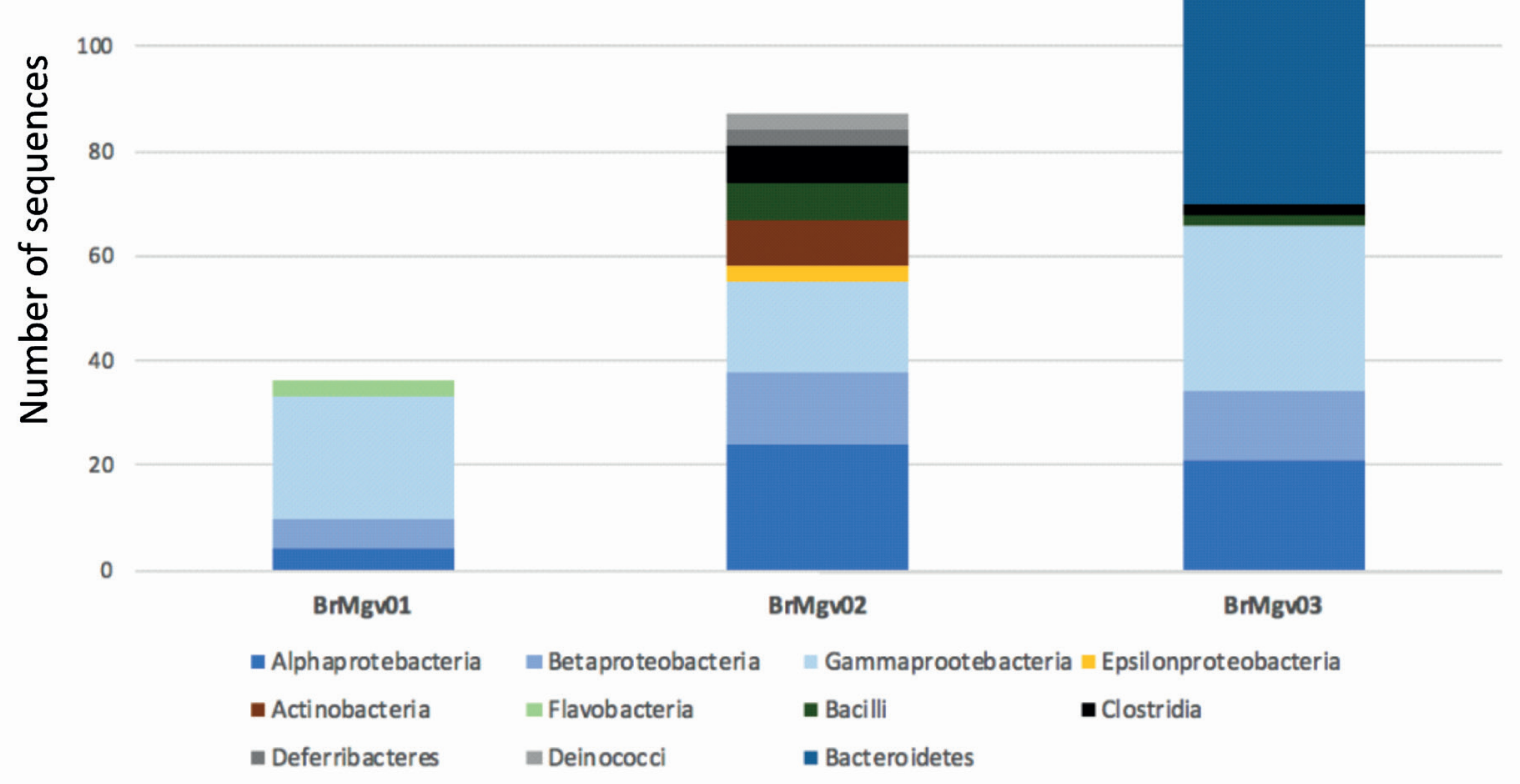

b

50

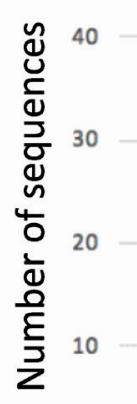

0

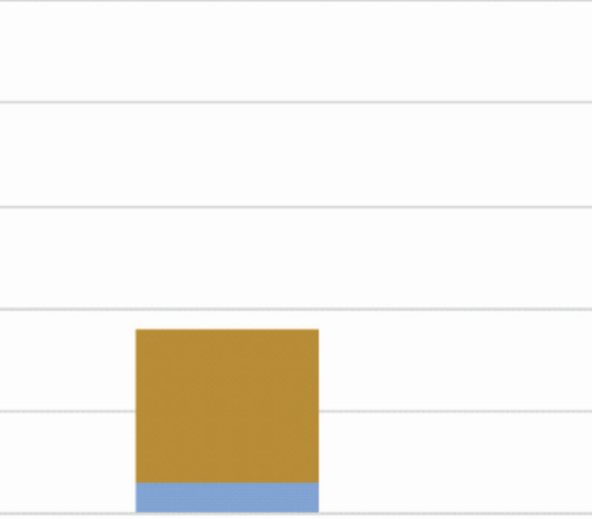

BrMgv01

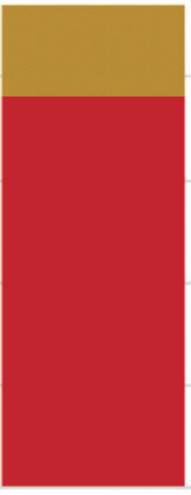

BrMgv02

BrMgv03

घetaproteobacteria $\square$ Deltaproteobacteria $\quad$ Planctomycetia

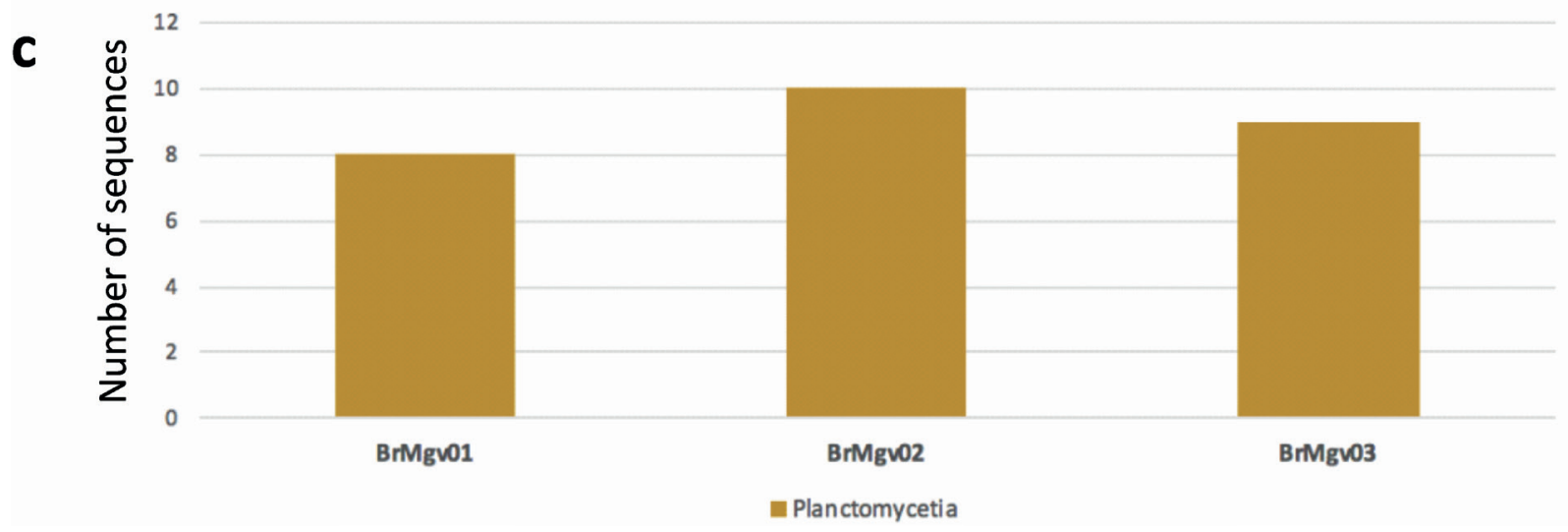

Figure 4 - The taxonomic affiliation of metagenome sequences related to (a) denitrification, (b) anammox and (c) DNRA. 
fraction of the reduced $\mathrm{NO}_{3}{ }^{-}$is released liberated as $\mathrm{NO}_{2}^{-}$. In such circumstances, anammox may not be able to keep up with denitrification when electron donor availability is high. Such a phenomenon might be occurring in mangrove soils, which have considerable organic carbon content. Dalsgaard et al. (2003) also evidence that denitrifiers have a higher growth rate than bacteria performing anammox, what can also explain the higher rates of denitrification reported here. Regarding affiliation of the gene sequences involved in anammox process, hh, hao and $h z$ genes, we observed that they were mostly affiliated with Planctomycetes, which is consistent with previous observations; as far as we know, anaerobic ammonium oxidation is performed by a monophyletic group of bacteria within the phylum Planctomycetes (Schmid et al. 2000, 2003).

Dissimilatory nitrate reduction to ammonium (DNRA) is an anaerobic microbial pathway that occurs in reductive environments capable of maintaining anaerobic metabolism, conditions that are generally thought to occur only in flooded environments (Tiedje 1988). Several studies have reported the occurrence of DNRA in soils, sediments, anoxic zones in waters and other sites, and that DNRA bacteria are generally found in anoxic environments with low nitrate availability anoxic (Kraft et al. 2011, Fernandes et al. 2012). DNRA and denitrification are two microbial processes that compete for nitrite and nitrate in the environment (van den Berg et al. 2016). However, while there is general agreement that denitrification process takes place in many soils, the occurrence, importance and drivers of DNRA are generally not considered (Meyer et al. 2005, Kraft et al. 2011). Here we observed for DNRA a similar trend that was observed for denitrification and anammox, but differences between the oil-affected area and the others were lower than the differences observed in denitrification or anammox rates. Furthermore, mangrove BrMgv03 showed the highest amount of
$\mathrm{NO}_{x}$ - consumption, suggesting that DNRA pathway might be important in BrMgv03, and maybe much more important than presently realized.

The soil oxidation state is the principal factor that influences rates of DNRA (Matheson et al. 2002, Brunel et al. 1992), with DNRA by bacteria and fungi occurring under more reducing (anoxic) conditions (Takaya 2002, Yin et al. 2002, Jones et al. 2008), as compared with denitrification. On the other hand, other studies showed that DNRA is less sensitive to variable redox conditions (Pett-Ridge et al. 2006) and less sensitive to $\mathrm{O}_{2}$ than denitrification (Lavik et al. 2009). Recently it has been confirmed experimentally that the organic carbon to nitrate and nitrite ratio and the availability of nitrite versus nitrate play a role on whether denitrification or DNRA processes dominate, as well as the generation time of the microbes (Kraft et al. 2014). Because generation time is very difficult to measure in sediments it has been overlooked so far.

The capability to perform DNRA is widely distributed among bacteria. Tiedje (1988) listed several genera of soil bacteria, which are obligate anaerobes (Clostridium), facultative anaerobes (Citrobacter, Enterobacter, Erwinia, Escherichia, Klebsiella) or aerobes (Bacillus, Pseudomonas), capable of performing DNRA. Our results corroborate these findings where we observed a high predominance of DNRA related sequences affiliated with Gammaproteobacteria.

Finally, the rate and flow of different types of nitrogen compounds in a mangrove ecosystem depends on the characteristics of the system. According to Alongi (2002), common disturbances, e.g. oil spills, can shift a healthy decomposing aerobic-anaerobic system of the mangrove to a complete anaerobic system, which is less efficient and slow in recycling nutrients, resulting in the buildup and release of toxic sulfides. Rates observed for denitrification/anammox activity can be a direct output of the contamination in mangroves sampled; it can also affect $\mathrm{NH}_{4}^{+}$availability in these sites, 
which influence directly all nitrogen cycle. Similarly, many other environmental factors can be affecting these nitrogen pathways in mangrove soils: e.g. the differences in sediment grain size, organic content, and $\mathrm{H}_{2} \mathrm{~S}$, difference in water movement, air-exposure frequency, and plant cover (Koop-Jakobsen et al. 2010).

\section{ACKNOWLEDGMENTS}

This work was supported financially by the Fundação de Amparo à Pesquisa do Estado de São Paulo (FAPESP, proc. numbers 2004/139106, 2012/06245-2 and 2015/01290-8), and D.M. Luvizotto received a graduate fellowship from Conselho Nacional de Desenvolvimento Científico e Tecnológico (CNPq, proc. number 201832/2010-0). We thank João L. Silva for the mangrove expeditions and sampling; Theresa Hargesheimer, Zanaib Saab (from MPI), Francisco Dini Andreote, Maryeimy V. Lopez, Luana L. Cadete (from ESALQ), for technical support. This study was financed in part by the Coordenação de Aperfeiçoamento de Pessoal de Nível Superior Brasil (CAPES) - Finance Code 001.

\section{REFERENCES}

ALLISON SD AND MARTINY JBH. 2008. Resistance, resilience, and redundancy in microbial communities. Proc Natl Acad Sci USA 105: 11512-11519.

ALONGI DM. 2002. Present state and future of the world's mangrove forests. Environ Conserv 29: 331-349.

AMANO T, YOSHINAGA I, VAN THUOC C, THE THU P, UEDA S, KATO K, SAKO Y AND SUWA Y. 2011. Contribution of anammox bacteria to benthic nitrogen cycling in a mangrove forest and shrimp ponds (Haiphong, Vietnam). Microb Environ 26: 1-6.

ANDREOTE FD, JIMENEZ DJ, CHAVES D, DIAS ACF, LUVIZOTTO DM, DINI-ANDREOTE FASANELLA CC, BAENAS S, TAKETANI RG AND MELO SI. 2012 The microbiome of Brazilian mangrove sediments as revealed by metagenomics. Plos ONE 7(6): e38600.

BALK M, KEUSKAMP JA AND LAANBROEK HJ. 2016. Potential for sulfate reduction in mangrove forest soils: Comparison between two dominant species of the Americas. Front Microb 7: 1855
BALK M, LAVERMAN AM, KEUSKAMP JA, LAANBROEK HJ. 2015. Nitrate ammonification in mangrove soils: a hidden source of nitrite? Front Microbiol 2015(6): 166.

BONIN P. 1996. Anaerobic nitrate reduction to ammonium in two strains isolated from coastal marine sediment: a dissimilatory pathway. FEMS Microbiol Ecol 19: 27-38.

BRAMAN RS AND HENDRIX AS. 1989. Nanogram nitrite and nitrate determination in environmental and biological materials by vanadium (III) reduction with chemiluminescence detection. Anal Chem 61: 2715-2718.

BRUNEL B, JANSE JD, LAANBROEK HJ AND WOLDENDORP JW. 1992. Effect of transient oxic conditions on the composition of the nitrate-reducing community from the rhizosphere of Typha angustifolia. Microb Ecol 24: 51-61.

CAO W, GUAN Q, LI Y, WANG M AND LIU B. 2017. The contribution of denitrification and anaerobic ammonium oxidation to $\mathrm{N}_{2}$ production in mangrove sediments in Southeast China. J Soils Sedim 17: 1-10.

CHOI A, CHO H, KIM SH, THAMDRUP B, LEE S AND HYUN JH. 2016. Rates of $\mathrm{N}_{2}$ production and diversity and abundance of functional genes associated with denitrification and anaerobic ammonium oxidation in the sediment of the Amundsen Sea Polynya, Antarctica. Deep Sea Res Part 2 Top Stud Oceanogr 123: 113-125.

CHON K, CHANG J, LEE E, LEE J, RYU J AND CHO J. 2009. Abundance of denitrifying genes coding for nitrate (nar $G$ ), nitrite (nir $S$ ), and nitrous oxide (nos $Z$ ) reductases in estuarine versus wastewater effluent-fed constructed wetlands. Ecol Eng 37: 64-96.

CROMPTON TR. 2005. Analysis of seawater - a guide for the analytical and environmental chemist. Berlin: Springer.

DALSGAARD T, CANFIELD DE, PETERSEN J, THAMDRUP B AND ACUÑA-GONZÁLEZ J. 2003. $\mathrm{N}_{2}$ production by the anammox reaction in the anoxic water column of Golfo Dulce, Costa Rica. Nature 422: 606-608.

DIAS ACF, SILVA MDCP, COTTA SR, DINI-ANDREOTE F, SOARES FL, SALLES JF, AZEVEDO JL, VAN ELSAS JD AND ANDREOTE FD. 2012. Abundance and genetic diversity of nifH gene sequences in anthropogenically affected Brazilian mangrove sediments. Appl Environ Microbiol 78: 7960-7967.

DONG LF, SMITH CJ, PAPASPYROU S, STOTT A, OSBORN AM AND NEDWELL DB. 2009. Changes in benthic denitrification, nitrate ammonification, and anammox process rates and nitrate and nitrite reductase gene abundances along an estuarine nutrient gradient (the Clone Estuary, United Kingdom). Appl Environ Microb 75: 3171-3179.

FERNANDES SO, BONIN PC, MICHOTEY VD, GARCIA N AND BHARATHIA PAL. 2012. Nitrogen-limited 
mangrove ecosystems conserve $\mathrm{N}$ through dissimilatory nitrate reduction to ammonium. Sci Rep 2: 419.

FERREIRA TO, OTERO XL, SOUZA VS JR, VIDALTORRADO P, MACÍAS F AND FIRME LP. 2010. Spatial patterns of soil attributes and components in a mangrove system in Southeast Brazil (São Paulo). J Soil Sediment 10: 995-1006.

FRANCIS CA, BEMAN JM AND KUYPERS MM. 2007. New processes and players in the nitrogen cycle: the microbial ecology of anaerobic and archaeal ammonia oxidation. ISME J 1: 19-27.

GHOSH A, DEY N, BERA A, TIWARI A, SATHYANIRANJAN KB, CHAKRABARTI K AND CHATTOPADHYAY D. 2010. Culture independent molecular analysis of bacterial communities in the mangrove sediment of Sundarban, India. Sal Sys 6: 1 .

GIBLIN AE, TOBIAS CR, SONG B, WESTON N, BANTA GT AND RIVERA-MONROY VH. 2013. The importance of dissimilatory nitrate reduction to ammonium (DNRA) in the nitrogen cycle of coastal ecosystems. Oceanography 26(3):124-131.

GLOCKNER A, JUNGST A AND ZUMFT W. 1993. Copper containing nitrite reductases from Pseudomonas aureofaciens is functional in mutationally cytochrome cd1-free background (NirS-) of Pseudomonas stutzeri. Arch Microbiol 160: 2136-2141.

HANSEN A, THAMDRUP B AND JØRGENSEN B. 2000. Anoxic incubation of sediment in gas-tight plastic bags: a method for biogeochemical process studies. Mar ecol 208: 273-282.

HOLGUIN G, BASHAN Y, MENDOZA-SALGADO RA, AMADOR E, TOLEDO G, VAZQUEZ P AND AMADOR A. 1999. La Microbiologia de los manglares. Bosques en la frontera entre el mar y la tierrra. Ciencia Desarrollo 144: 26-35.

HOLGUIN G, VAZQUEZ P AND BASHAN P. 2001. The role of sediment microorganisms in the productivity, conservation, and rehabilitation of mangrove ecosystems: an overview. Biol Fert Soils 33: 265-278.

HOLTAPPELS M, LAVIK G, JENSEN MM AND KUYPERS MMM. 2011. ${ }^{15} \mathrm{~N}$ labeling experiments to dissect the contributions of heterotrophic denitrification and anammox to nitrogen removal in the OMZ waters of the Ocean, $\mathrm{p}$. 223-251. In: Klotz MG (Ed), Methods in Enzymology, Vol 486.

JETTEN MS, VAN NIFTRIK L, STROUS M, KARTAL B, KELTJENS JT AND OP DEN CAMP HJM. 2009. Biochemistry and molecular biology of anammox bacteria. Crit Rev Biochem Mol Biol 44: 65-84.

JIANG XT, PENG X, DENG GH, SHENG HF, WANG Y, ZHOU HW AND TAM NFY. 2013. Illumina sequencing of $16 \mathrm{~S}$ rRNA tag revealed spatial variations of bacterial communities in a mangrove wetland. Microb Ecol 66: 96104.

JONES CM, STRES B, ROSENQUIST M AND HALLIN S. 2008. Phylogenetic analysis of nitrite, nitric oxide, and nitrous oxide respiratory enzymes reveal a complex evolutionary history for denitrification. Mol Biol Evol 25: 1955-1966.

KOOP-JAKOBSEN K, GIBLIN A AND KUENEN JG. 2010. Anammox bacteria: from discovery to the effect of increased nitrate loading on nitrate reduction via denitrification and DNRA in salt marsh sediments. Limno Oceanogr 55: 789-802.

KRAFT B, STROUS M AND TEGETMEYER HE. 2011. Microbial nitrate respiration - genes, enzymes and environmental distribution. J Biotechnol 155: 104-117.

KRAFT B, TEGETMEYER H, SHARMA R, KLOTZ M, FERDELMAN T, HETTICH R, GEELHOED J AND STROUS M. 2014. The environmental controls that govern the end product of bacterial nitrate respiration. Science 345: 676-679.

LACERDA LD, CONDE JE, ALARCON C, ALVAREZLEON R, BACON PR, D'CROZ LD, KJERFVE B, POLANIA J AND VANNUCCI M. 1993. Ecosistemas de manglar de America Latina y el Caribe:sinopsis. In: Lacerda LD and Polania J (Eds), Conservacion y aprovechamiento sostenible de bosques de manglar en las regiones America Latina y Africa. International Tropical Timber Organization and International Society for Mangrove Ecosystems, Okinawa, p 1-38.

LAVIK G ET AL. 2009. Detoxification of sulphidic African shelf waters by blooming chemolithotrophs. Nature 457: 581-584.

MATHESON FE, NGUYEN ML, COOPER AB, BURT TP AND BULL DC. 2002. Fate of ${ }^{15} \mathrm{~N}$-nitrate in unplanted, planted and harvested riparian wetland soil microcosms. Ecol Eng 19: 249-264.

MEYER F ET AL. 2008. The metagenomics RAST server: a public resource for the automatic phylogenetic and functional analysis of metagenomes. BMC Bioinformatics 9(386): 1-8.

MEYER RL, RISGAARD-PETERSEN N AND ALLEN DE. 2005. Correlation between anammox activity and microscale distribution of nitrite in a subtropical mangrove sediment. Appl Environ Microbiol 71: 6142-6149.

MOHAN SB AND COLE JA. 2007. The dissimilatory reduction of nitrate to ammonia by anaerobic bacteria. In: Bothe H, Ferguson S and Newton WE (Eds), Biology of the nitrogen cycle. Elsevier, Amsterdam, p 93-106.

MULDER A, VAN DE GRAAF AA, ROBERSTON LA, AND KUENEN JG. 1995. Anaerobic ammonium oxidation discovered in a denitrifying fluidized-bed reactor. FEMS Microbiol Ecol 16: 177-183.

NIJBURG JW, COOLEN MJL, GERARDS S, KLEIN GUNNEWIEK PJAAND LAANBROEK HJ. 1997. Effects of nitrate availability and the presence of Glyceria maxima 
on the composition and activity of the dissimilatory nitrate reducing bacteria community. Appl Environ Microbiol 63: 931-937.

NOGUEIRA VL, ROCHA LL, COLARES GB, ANGELIM AL, NORMANDO LR, CANTÃO ME AND MELO VM. 2015. Microbiomes and potential metabolic pathways of pristine and anthropized Brazilian mangroves. Reg St Mar Sci 2: 56-64.

PADISÁK J, REYNOLDS CS AND SOMMER U. 1993. Intermediate Disturbance Hypothesis in Phytoplankton Ecology. Kluwer Academic Publishers, Dordrecht.

PETT-RIDGE J, SILVER WL AND FIRESTONE MK. 2006. Redox fluctuations frame microbial community impacts on $\mathrm{N}$-cycling rates in humid tropical forest soil, Biogeochemistry 81: 95-110.

QUAN ZX, RHEE, SK, ZUO JE, YANG Y, BAE JW, PARK JR, LEE ST AND PARK YK. 2008. Diversity of ammonium-oxidizing bacteria in a granular sludge anaerobic ammonium-oxidizing (anammox) reactor. Environ Microbiol 10: 3130-3139.

REYNA L, WUNDERLIN DA AND GENTI-RAIMONDI S. 2010. Identification and quantification of a novel nitratereducing community in sediments of Suqua River basin along a nitrate gradient. Environ Pollut 158: 1608-1614.

RISGAARD-PETERSEN N, NIELSEN LP, RYSGAARD S, DALSGAARD T AND MEYER RL. 2003. Application of the isotope pairing technique in sediments where anammox and denitrification coexist. Limnol Oceanogr Meth 1: 63-73.

RIVERA-MONROY VH AND TWILLEY RR. 1996. The relative role of denitrification and immobilization in the fate of inorganic nitrogen in mangrove sediments (Terminos Lagoon, Mexico). Limnol Oceanogr Meth 41: 284-296.

SAHOO KD AND DHAL NK. 2009. Potential microbial diversity in mangrove ecosystems: A review. Ind J Mar Sci 38: 249-256.

SCHMID M, TWACHTMANN U, KLEIN M, STROUS M, JURETSCHKO S, JETTEN M, METZGER JW, SCHLEIFER KH AND WAGNER M. 2000. Molecular evidence for genus level diversity of bacteria capable of catalyzing anaerobic ammonium oxidation. Syst Appl Microbiol 23: 93-106.

SCHMID M ET AL. 2003. Candidatus "Scalindua brodae", sp. noc., Candidatus "Scalindua wagneri", sp. nov., two new species of anaerobic ammonium oxidizing bacteria. Syst Appl Microbiol 26: 529-538.

SHIMAMURA M, NISHIYAMA T, SHIGETOMO $\mathrm{H}$, TOYOMOTO T, KAWAHARA Y, FURUKAWA K AND FUJII T. 2007. Isolation of a multiheme protein with features of a hydrazine-oxidizing enzyme from an anaerobic ammonium-oxidizing enrichment culture. Appl Environ Microbiol 73: 1065-1072.
SOLÓRZANO L. 1969. Determination of ammonia in natural waters by the phenolhypochlorite. Limnol Oceanogr Meth 14: 799-801.

STROUS M AND JETTEN MSM. 2004. Anaerobic oxidation of methane and ammonium. Rev Microb 58: 99-117.

STROUS M, FUERST JA, KRAMER EHM, LOGEMANN S, MUYZER G, VAN DE PAS-SCHOONEN KT, WEBB R, KUENEN JG AND JETTEN MSM. 1999. Missing lithotroph identified as new planctomycete. Nature 400: 446-449.

TAKAYA N. 2002. Dissimilatory nitrate reduction metabolisms and their control in fungi. J Biosci Bioeng 94: 506-510.

THAMDRUP B AND DALSGAARD T. 2002. Production of $\mathrm{N}_{2}$ through anaerobic ammonium oxidation coupled to nitrate reduction in marine sediments. Appl Environ Microbiol 68: 1312-1318.

THOMPSON CE ET AL. 2013. A potential source for cellulolytic enzyme discovery and environmental aspects revealed through metagenomics of Brazilian mangroves. AMB Express 3: 65.

THROBACK IN, ENWALL K, JARVIS A AND HALLIN S. 2004. Reassessing PCR primers targeting nirS, nirK and nos $Z$ genes for community surveys of denitrifying bacteria with DGGE. FEMS Microbiol Ecol 49: 401-417.

TIEDJE JM. 1988. Ecology of denitrification and dissimilatory nitrate reduction to ammonium. Pages 179-244 in AJ. Zehnder, editor, Biology of anaerobic microorganisms. Wiley-Interscience, Ontario, Canada.

TRIMMER M, NICHOLLS JC AND DEFLANDRE B. 2003. Anaerobic ammonium oxidation measured in sediments along the thames estuary, United Kingdom. Appl Environ Microbiol 69: 6447-6454.

VAN DEN BERG EM, BOLEIJ M, KUENEN JG AND KLEEREBEZEM RANDVAN LOOSDRECHT MCM. 2016. DNRA and denitrification coexist over a broad range of acetate $/ \mathrm{N}^{-N}{ }_{3}^{-}$ratios, in a chemostat enrichment culture. Front Microbiol 7: 1842.

VAN RAIJ B, CANTARELLA H, ANDRADE JC AND QUAGGIO JÁ. 2001. Análise química para avaliação da fertilidade de solos tropicais. Campinas: Instituto Agronômico, $285 \mathrm{p}$

YIN SX, CHEN D, CHEN LM AND EDIS R. 2002. Dissimilatory nitrate reduction to ammonium and responsible microorganisms in two Chinese and Australian paddy soils. Soil Biol Biochem 34: 1131-1137.

\section{SUPPLEMENTARY MATERIAL}

Table SI - Amounts of nitrite (in $\mathrm{mg} / \mathrm{L}$ ) in mangrove soil samples along the experiment.

Table SII - Number of sequences affiliated to functional genes involved in the nitrogen transformations found in mangrove soils metagenomes. 